\title{
ROLA RZEZI WOŁYŃSKIEJ W BUDOWANIU NARRACJI NA TEMAT UKRAIŃCÓW W POLSKIM INTERNECIE
}

\section{Katarzyna Krakowska*}

\author{
Abstrakt \\ Praca stanowi analizę wątków historycznych - ze szczególnym uwzględnieniem \\ problematyki rzezi wołyńskiej - w dyskursie na temat Ukraińców i ukraińskich \\ imigrantów w polskich mediach społecznościowych. Została zrealizowana przy \\ użyciu narządzi CAQDAS w oparciu o materiał źródłowy zgromadzony jesienią \\ 2016 roku.
}

Słowa kluczowe: Ukraina, Ukraińcy, historia, Wołyń, dyskurs, krytyczna analiza dyskursu, Internet

\section{THE ROLE OF VOLHYNIA MASSACRE IN BUILDING A NARRATIVE ABOUT UKRAINIANS ON THE POLISH INTERNET}

\begin{abstract}
The paper is an analysis of historical issues - with particular emphasis on the problems of the slaughter of Volhynia - in the discourse on Ukrainians and Ukrainian immigrants in the Polish Internet. The paper was realized using CAQDAS software tools based on source material collected in autumn 2016.
\end{abstract}

Keywords: Ukraine, Ukrainians, history, Volhynia, discourse, critical discourse analysis, Internet

\footnotetext{
* Katarzyna Krakowska, Koło Socjologii Collegium Civitas, kasiakrakowska@gmail.com.
} 
„Stosunki Ukrainy z Polską są trudne i obfitują w sprzeczności. Oba krajełączy sześćset lat wspólnej historii, najpierw pod panowaniem polskich królów, a następnie między innymi pod rządami rosyjskich carów. Ale niczym rywalizujące rodzeństwo każde z tych państw lubi określać się w opozycji do drugiego, zamiast szukać jakichkolwiek podobieństw. Polska jest w tych stosunkach wyniosła i z lekka dramatyzuje; Ukraina - pozbawiona możliwości ekspresji i z lekka wykorzystywana. Ukraina ma za złe Polsce ciągłe wypychanie się na pierwszy plan, Polska zarzuca Ukrainie podkradanie jej »najlepszych kwestii «"- tak o relacjach polsko-ukraińskich pisze wswojej pracy Pogranicze Anna Reid (2016: 103104). Obraz ten, choć pełen nieścisłości i mający publicystyczny, nieco prowokacyjny charakter, jest szalenie inspirujący. Wskazuje on bowiem na rangę kontekstu historycznego w relacjach polsko-ukraińskich.

Biorąc pod uwagę aktualną sytuację społeczno-polityczną, a także ekonomiczną na Ukrainie, liczyć należy się z tym, że i tak znacząca już liczba imigrantów z tego kraju w Polsce może w dalszym ciągu rosnąć. Obserwowanie stosunku Polaków do przyjezdnych ze Wschodu jest szczególnie ważne, jeśli uwzględnimy pewną pobłażliwość, a nawet poparcie znacznej części klasy politycznej dla narastających w naszym kraju nastrojów skrajnie nacjonalistycznych i ksenofobicznych.

Celem pracy jest analiza wątku rzezi wołyńskiej w dyskursiena temat Ukraińców w polskim Internecie oraz jego znaczenia dla kształtowania wizerunku współczesnego Ukraińca (w tym ukraińskiego imigranta w Polsce). Wątki historyczne, a w szczególności temat mordów na Wołyniu w latach 40. XX wieku okazał się być najistotniejszym i budzącym najsilniejsze emocje elementem dyskursu na temat Ukraińców w polskich mediach społecznościowych, którego analizy podjął się Marek Troszyński (2018).

Podstawą analizy stały się materiały, pochodzące z polskich mediów społecznościowych, zebrane przy użyciu komercyjnej platformy sentione.com na wstępnym etapie realizacji projektu Ukraina i Ukraincy 
$w$ polskim dyskursie internetowym. Analiza jakościowo-ilościowa tekstów zamieszczanych $w$ mediach spolecznościowych realizowanego w ramach projektów badawczych Collegium Civitas przez Marka Troszyńskiego'.

Analizie poddano materiał źródłowy składający się wstępnie z ok. 23000 wpisów zaimportowanych z sieci i wybranych do tego celu losowo spośród ok. 100000 tego typu wypowiedzi, które pojawiły się w mediach społecznościowych we wrześniu 2016 roku. Zcałego korpusu tekstów wyodrębniono niespełna 10000 cytatów, którym przypisano właściwekody, pomocne przy analizie. Arkusz kodowy składał się z trzech części. Pierwsza z nich zawierała kody pozwalające na określenie sentymentu wypowiedzi. Zgodnie z założeniem każda wypowiedź powinna mieć określony poziom (lub brak) negatywności, bądź pozytywność, jednak na 9906 cytatów tylko 2760 posiadało określenie sentymentu; ponadto zaobserwowano znaczące różnice w rozumieniu poziomów negatywności - 1i 22. W części drugiej znajdowały się kody wskazujące na obszary tematyczne. Część trzecia zawierała kody „inne” - zamieszczono w niej „dodatkowe kategorie traktowane jako zmienne binarne (występuje/nie występuje), które pozwolą na zakodowanie dodatkowych informacji o poszczególnych fragmentach tekstów" (Troszyński 2018: 113) ${ }^{3}$.

Znaczenie rzezi wołyńskiej w polsko-ukraińskiej historii

Od uczestników dyskusji na temat relacji między dwoma narodami, a szczególnie kontekstu historycznego tychże relacji, chciałoby się wy-

\footnotetext{
1 Projekt zrealizowano dzięki grantowi Fundacji im. Stefana Batorego

${ }^{2}$ Analizowane materiały zbierane były na wstępnym etapie projektu badawczego, stąd pewne niedoskonałości w stosowaniu narzędzia.

3 Szczegółowe omówienie klucza kodowego, przebiegu kodowania oraz jakościową i ilościową analizę pełnego korpusu tekstów znaleźć można w: Troszyński 2018.
} 
magać dobrej znajomości historii obu narodów. Ogrom wiedzy jaką należałoby w tym celu posiąść jest jednak wręcz onieśmielający ${ }^{4}$. Mimo to, szczególnie od pojawienia się w kinach filmu Wotyń Wojciecha Smarzowskiego, historyczny obraz narodu ukraińskiego oraz relacji polskoukraińskich stał się przedmiotem zagorzałych dyskusji w polskim Internecie.

O ile jednak sam fakt uczestniczenia internautów w dyskusjach na tematy, o których nie mają większej wiedzy, niejest zjawiskiem nowym, ani specjalnie zaskakującym, to zakres tej dyskusji, jej język i skutki, jakie może spowodować stając się elementem szerszego dyskursu na temat Ukraińców, jest z socjologicznego punktu widzenia ciekawy i ważny.

Rzeź wołyńska 1943 roku była akcją zaplanowaną i przeprowadzoną przez rodzący się ukraiński ruch nacjonalistyczny ${ }^{5}$, przy udziale ukraińskich chłopów, wymierzoną w polską ludność cywilną zamieszkującą na ziemiach Wołynia. Były to wyjątkowo krwawe i brutalne czystki, które pochłonęły, według Grzegorza Motyki (2011: 852-853), ok. 100 tysięcy ofiar. Co prawda władze ukraińskie nigdy oficjalnie tego nie przyznały, ale wydarzenia wołyńskie dość powszechnie uznaje się za zbrodnię ludobójstwa ${ }^{6}$.

Choć dziś nikt już raczej nie podaje w wątpliwość autentyczności doniesień dotyczących zdarzeń 1943 roku, to zdania na temat ich przyczyn, charakteru i źródła inspiracji są mocno podzielone. Dominują dwa skrajne podejścia. Według pierwszego z nich zbrodnia ta była przejawem morderczej natury narodu ukraińskiego, który w sprzyjających

\footnotetext{
4 Szczególnie uwzględniając polifoniczność historiografów w odniesieniu do niemal każdego etapu historii Ukrainy czy też protoukraińskich organizmów państwowych.

5 Przede wszystkim mam tu na myśli przywódców OUN-B, ale także działaczy UPA.

${ }^{6} 22$ lipca 2016 Sejm RP - w związku z 73 rocznicą rzezi wołyńskiej - przyjął uchwałe, w której po raz pierwszy nazwał te wydarzenia zbrodnią ludobójstwa-Uchwała Sejmu Rzeczypospolitej Polskiej z dnia 22 lipca 2016 r. w sprawie oddania hołdu ofiarom ludobójstwa dokonanego przez nacjonalistów ukraińskich na obywatelach II Rzeczypospolitej Polskiej w latach 1943-1945. We wcześniejszych latach stosowano co najwyżej określenie „czystka etniczna o znamionach ludobójstwa” - Uchwała Sejmu Rzeczypospolitej Polskiej z dnia 12 lipca 2013 r. w sprawie uczczenia 70. Rocznicy Zbrodni Wołyńskiej i oddania hołdu Jej ofiarom.
} 
warunkach dał upust swej demonicznej wręcz rządzy zabijania (Motyka 2016: 9). Narracja znajdująca się na drugim krańcu przedstawia natomiast te same wydarzenia jako w pełni uprawniony bunt chłopów ukraińskich, będący reakcją na ucisk i skrajnie złe traktowanie. Ich polscy sąsiedzi mieli zatem przyjąć na siebie odpowiedzialność za represyjność II Rzeczpospolitej, a także wcześniejsze przejawy polskiej dominacji (ibidem: 37). „W tak skonstruowanej opowieści to polskie ofiary powinny się tłumaczyć z tego, co się stało. Bezlitosne postępowanie »polskich panów« wywołało »symetryczną« społeczną reakcję. Sprawcy właściwie nie mieli innego wyjścia niż przeciwstawienie się siłą i okrucieństwem »katolickiemu odczłowieczeniu«. O ile wina polska jest zindywidualizowana, to sprawcy są jedynie drobnym trybikiem w maszynie rzekomej konieczności historycznej, zaledwie bezwolną cząstką wody potężnego społecznego tsunami, ich czyny pozostają więc tak naprawdę poza dobrem i złem”, komentuje Grzegorz Motyka (Ibidem: 17).

Autor pracy Wotyń '43 daleki jest jednak od przyjęcia pierwszego punktu widzenia, mówiącego o zbrodniczej naturze Ukraińców czy też demonicznym charakterze tej zbrodni. Przeciwnie - twierdzi, że obie powyższe perspektywy są, wbrew pozorom, bardzo do siebie podobne, ponieważ „w obu opowieściach sprawcami masowych mordów okazują się zwykli chłopi, którzy jakoby powszechniei dość spontanicznie chwycili za siekiery przeciwko polskim sąsiadom" (Ibidem: 18). Motyka w swoich pracach analizuje bogate źródła historyczne dowodzące, że nie jest to obraz prawdziwy - rzeź wołyńska była zaplanowanym działaniem przywódców ruchów nacjonalistycznych. Intencjonalna była zarówno jej niesłychana brutalność, jak i pozorowana spontaniczność: „masowe mordy ludności polskiej były dokonywane tak brutalnie, ponieważ sprawcy tej zorganizowanej zbrodni tak to zaplanowali, słusznie niestety zakładając, że nic lepiej nie ukryje charakteru dokonanych przez nich czynów, jak »ubranie ich w szaty « chłopskiego buntu” (Ibidem: 19). 
Krytyczna analiza dyskursu - główne założenia i status teoretyczno-metodologiczny

Przez wzgląd na popularność jaką termin dyskurs zdobył w ostatnich latach zadaniem zasadniczym, a przy tym brzemiennym w skutki dla mojej pracy badawczej, jest przyjęcie jednej z wielu bardzo różnorodnych definicji dyskursu. O dyskursie zwykło mówić się dawniej w odniesieniu do wypowiedzi mówionych. Miało to swoje źródła w klasycznych teoriach lingwistycznych, które wypowiedzi pisane określały mianem tekstu, natomiast do języka mówionego stosowały pojęcia takie jak wypowiedź, dyskurs czy rozmowa. J ednak, jak za Anną Duszak, stwierdza Barbara J abłońska „Współczesne podejście w badaniach nad dyskursem uwzględnia (..) w równym stopniu wypowiedź oraz tekst jako element składowy analizy" (J abłońska 2006: 55).

Zakładając, że w polu moich zainteresowań badawczych znajdować się będą wypowiedzi formułowane w tak zwanym „pisanym języku mówionym” (Herma 2014), zdecydowałam się przyjąć definicję dyskursu, która będzie wystarczająco otwarta, aby uznać ten typ wypowiedzi za mogący znaleźć się w polu zainteresowania, a zarazem na tyle precyzyjna, by stanowić solidny punkt wyjścia do teoretycznych rozważań na temat tego, czym winna być analiza dyskursu.

Za najbardziej przekonywające uznałam rozumienie dyskursu przyjęte przez holenderskiego badacza Teuna van Dijka (2001: 11), który uważa, że w badaniach nad dyskursem poświęcać należy tyleż uwagi językowi mówionemu (wypowiedziom), co pisanemu (tekstowi). Van Dijk podkreśla, że w obu formach języka odnaleźć można podobne środki, którymi nadawca stara się wywrzeć wpływ na odbiorcę. Ważna jest dla niego również aktywność obu stron procesu komunikacji. Niezależnie od tego, czy jest to komunikacja bezpośrednia czy zapośredniczona, a przy tym posługująca się komunikatem pisanym, interaktanci dokonują pewnego wysiłku związanego zarówno z nadaniem, jak i odczytaniem 
komunikatu: „Możemy więc też mówić o komunikacji pisemnej, choć jej uczestnicy nie kontaktują się ze sobą twarzą w twarz, a czytelnicy bardziej pasywnie uczestniczą w interakcji. Z wyjątkiem wymiany korespondencji oraz debaty w mediach, rzadko mają oni możliwość odpowiadania piszącym autorom. Nie znaczy to bynajmniej, że czytając i rozumiejąc teksty są mniej aktywni niż uczestnicy komunikacji ustnej" (ibidem: 11).

Inspirując się koncepcją van Dijka przez dyskurs rozumieć będę wypowiedź lub tekst istniejące w pewnym kontekście kulturowym, politycznym, społecznym i gospodarczym. Współtworzą go teksty czy wypowiedzi posiadające swoją formę i schemat, za którymi skrywają się znaczenia, a ich zdekodowanie prowadzi do odkrycia idei podzielanych przez uczestników dyskursu (Malewska-Szałygin 2004: 83). Co ważne - dyskurs jest procesem, a więc ma charakter dynamiczny (Dijk 2001: 28). Z socjologicznego punktu widzenia istotne jest również współoddziaływanie między dyskursem a społeczeństwem (Krzyżanowska 2013: 66), ponieważ - jak twierdzą Norman Fairclough i Ruth Wodak „dyskurs reprodukuje społeczeństwo i kulturę, będąc jednocześnie przez nie reprodukowanym" (za: ibidem).

Przystępując do analizy zdecydowałam się na przyjęcie perspektywy krytycznej (J abłońska 2006: 56), co wynika z mojego postrzegania społecznej roli badacza. Zasadnicza różnica pomiędzy analizą socjologiczną a studiami krytycznymi polega na tym, że w tych pierwszych mamy do czynienia wyłącznie z płaszczyzną opisowo-wyjaśniającą, drugie natomiast poszerzone są o płaszczyznę normatywną (Grzymała-Kazłowska 2004: 31). Przyjmując perspektywę krytyczną wychodzę zatem z założenia, żejednym z celów mojej pracy ma być próba wpłynięcia na rzeczywistość. Zidentyfikowanie problemów ma służyć znalezieniu sposobów ich rozwiązania, a nie być tylko celem samym w sobie. 
Retoryka wykluczenia w teorii dyskursu

Publikowanie postów czy komentarzy poświęconych imigrantom z Ukrainy czy Ukraińcom w ogóle, ich historii, tożsamości narodowej etc. jest niewątpliwie przejawem aktywności publicznej czy wręcz politycznej internautów i wpisuje się w dyskurs tożsamości. Co jednak istotne, „[d]yskurs i komunikacja polityczna zawsze wymagają rozróżnienia »my - oni«, co umożliwia zarówno budowanie pozytywnego wizerunku mówiących / piszących, jak i negatywnej charakterystyki przeciwników jako »obcych «" (Wodak 2008: 186). Dychotomiczny podział świata na „Swoich” (w domyśle - dobrych) i „obcych” (w domyśle - złych), umożliwia odbiorcy silną identyfikację z jedną z grup, a zarazem obarczenie drugiej winą za niepowodzenia czy krzywdy grupy własnej. Takie przeciwstawienie sobie dwóch grup i stosowanie środków retorycznych mających na celu jego podkreślenie są przejawami dyskursu perswazyjnego (Ibidem).

Od tego, czego dotyczy wspomniany wyżej przekazi w jakim kontekście się odbywa, uzależnione są stosowane na jego potrzeby środki. Wypowiedzi poświęcone trudnym historycznym relacjom międzypaństwowym mogą służyć obarczeniu winą jednej ze stron (w tym przypadku Ukraińców), a zarazem zarysowania ich obrazu przez pryzmat dokonanych zbrodni. Złudne poczucie anonimowości, jaką daje Internet, sprawia, że w wypowiedziach tam publikowanych ujawnić się może łatwiej retoryka różnicy i wykluczenia (Wodak 2008: 187). Ponadto, jak twierdzi Ruth Wodak, uznać należy „dyskursywne ustanowienie kategorii »my« i »oni « za najważniejszy zabieg na obszarze dyskursu tożsamości i różnicy, za najbardziej uderzającą cechę dyskursu populistycznego" (Ibidem: 196). 
Ukraińcy oczami polskich internautów

Pośród niemal 10000 cytatów, wyodrębnionych z całego korpusu tekstów przez koderów, kategoria tematyczna „historia” była jedną z trzech najczęściej wskazywanych (1117 oznaczonych nią cytowań), po „polityce” (1531) i „społeczeństwie” (1426). 334 razy oznaczono również kod „»Wołyń«”, jednak był on różnie rozumiany przez koderów więc de facto liczba ta nie wskazuje ani wypowiedzi poświęconych dziełu filmowemu, ani tych poświęconych rzezi wołyńskiej w ogóle (takich wypowiedzi było zdecydowanie więcej, choć nie zawsze padało w nich sformułowanie rzeź wołyńska czy nawet Wołyń).

Pod kodem „polityka” znalazły się wypowiedzi dotyczące aktualnej sytuacji politycznej w Polsce, politycznych i gospodarczych stosunków międzynarodowych oraz sytuacji wewnętrznej na Ukrainie i jej relacji z Rosją. Kod „społeczeństwo” przypisywano najczęściej wpisom na temat obecności imigrantów zarobkowych w Polsce (ich pozycji i stosunku do Polaków, jakości wykonywanej przez nich pracy oraz tego jak ich obecność wpływa na życie codzienne w Polsce), a także standardów życia na Ukrainie. Oczywiście częstokroć wypowiedzi łączyły w sobie wiele wątków tematycznych.

Choć kategoria „historia” nie była najobszerniejsza, to znalazły się w niej wypowiedzi najbardziej emocjonalne, często o negatywnym wydźwięku. Wspomniany we wstępie problem z nieokreślaniem przez koderów sentymentu na etapie testowym badania, z którego pochodzą dane, nie pozwala na rzetelną analizę ilościową sentymentu wypowiedzi w poszczególnych kategoriach. Myślę, że obraz ten dobrze oddają jednak dane zgromadzone na dalszym etapie badania. J ak podaje w swoim raporcie marek Troszyński pośród wypowiedzi z okresu od grudnia 2016 roku do listopada 2017 roku odsetek wypowiedzi negatywnych w kategorii „polityka” wynosił 32,7\%, w kategorii „społeczeństwo” 39\%, zaś w kategorii „historia” 48,1\% (Troszyński 2018: 110). Widać więc już 
na poziomie ilościowym, że tematy związane z przeszłością budzą najwięcej negatywnych emocji. Dopiero jednak analiza jakościowa oddaje w pelni charakter problemu.

Zakres tematyczny wypowiedzi poświęconych kwestiom historycznym jest stosunkowo wąski. Internauci odnoszą się w zasadzie do trzech podstawowych wątków:

- źródeł państwowości ukraińskiej i korzeni narodu ukraińskiego;

- współpracy z hitlerowskimi Niemcami w okresie II wojny światowej;

- rzezi wołyńskiej.

Wątkiem historycznym, który pojawia się zdecydowanie najczęściej w wypowiedziach internautów jest rzeź wołyńska, a także związane znią tematy Stepana Bandery, Ukraińskiej Powstańczej Armii i ukraińskiego nacjonalizmu. Wpisy związane z tą tematyką mają szczególnie mocny emocjonalny wydźwięk. Ton dyskursu obecnego w polskojęzycznym Internecie doskonale odzwierciedla amatorski tekst hiphopowy, który w całości lub we fragmentach pojawia się w analizowanych materiałach [Pisownia, składnia i interpunkcja wszystkich poniższej przytaczanych cytatów z Internetu jest oryginalna i nie była przez autorkę ani redakcję poprawiana]:

„Wroga Krew1.Ukraińska krew to wroga krew. J estem Polakiem Żaden Ukrainiec nie jest moim bratem $\mathrm{W}$ zgodzie $\mathrm{z}$ historią, a nie na bakier Niesie mnie prawda, nie powstrzyma żadna propaganda To walka o pamięć, nie wolno zapomnieć Co nam zrobili banderowcy, ich morderstw Gwałcili, zabijali kobiety, a małe dzieci, kurwa, nabijali na sztachety Kim trzeba być i co trzeba mieć w głowie? Tak nie zrobi nawet zwierzę, a co dopiero człowiek? Co to za nacja? To przeklęta swołocz Która zarzyna sąsiada, który mieszka od lat obok A nasi politycy stają z nimi ramię w ramię Lansując się na neo-banderowskim Majdanie Odzierając z godności bestialsko zabitych Polaków Wspierając potomków naszych katów REF: 2xZamknij oczy i weź sobie to wyobraź Kobieta gwałcona na oczach jej 
ojca Konające dzieci nabite na płotach Martwy mężczyzna z bagnetami w oczach Zarżnięta Matka z flakami na wierzchu Unoszący się zapach krwi w powietrzu Wyobraź to sobie siostro, bracie zanim zsolidaryzujesz się z Ukraińcami!"

Powyższą wypowiedź, podobnie jak ogromną liczbę wpisów na ten sam temat, charakteryzuje skrajnie negatywny sentyment widoczny w samej treści wypowiedzi, jaki wjej formie (stosowanie przekleństw oraz określeń i porównań obraźliwych - „przeklęta swołocz”, „tak nie zrobi nawet zwierzę”), a także w wezwaniach do działania („Wyobraź to sobie siostro, bracie zanim zsolidaryzujesz się z Ukraińcami!”, „Przestań popierać”). Obelgi, dehumanizacja oraz upokarzająca zoomorfizacja służą pokazaniu odmienności (gorszości) Ukraińców. Przedstawia się naszych sąsiadów jako wyraźnie różniących się od nas szczególną skłonnością do stosowania przemocy. Takjednoznaczne wskazywanie innego i chęć odróżnienia się od niego charakterystyczne są dla dyskursu wykluczenia opartego na opozycji swój-wróg (Witosz 2010: 16).

Znaczące są także naturalistyczne obrazy okrutnych tortur stosowane w powyższej i podobnych wypowiedziach, jak choćby powracające w refrenie słowa: „Kobieta gwałcona na oczach jej ojca”, „Konające dzieci nabite na płotach”, „Martwy mężczyzna z bagnetami w oczach”, „Zarżnięta Matka z flakami na wierzchu”. Podkreślają one poziom okrucieństwa i służą rozbudzeniu oburzenia, niezgody i aktywnego sprzeciwu. Warte śledzenia oraz dokładniejszej analizy są pojawiające się w polskim Internecie sugestie, że „pomścimy przodków” i „odzyskamy utracone ziemie” („Tam gdzie pomniki stoją bez głów, od zawsze była Polska i będzie Polska znów!"). Mają one charakter jawnego wzywania do agresji względem sąsiadów, których - poza wielością obraźliwych epitetów - określa się mianem „wrogów”.

Klaus Bachmann, omawiając podobne praktyki dyskursywne wkontekście kryzysu uchodźczego w Polsce i Europie, wykazuje, iż epatowanie rzekomą wrodzoną skłonnością do agresji i zezwierzęceniem obcych 
są przejawami dyskursu ksenofobicznego (Sydow 2016). J ego fundamentem jest strach przed tym co nieznane, obawa o suwerenność narodową, czystość kulturową, bezpieczeństwo ekonomiczne. Znamienne dla takiej narracji są nie tylko uwłaczające godności wypowiedzi o samych Ukraińcach, ale także ostrzeganie przed zagrożeniem wewnętrznym w postaci Polaków, którzy prezentowani są jako głupi, niedouczeni, zmanipulowani, a niekiedy nawet jako zdrajcy, ponieważ odnoszą się przyjaźnie do naszych wschodnich sąsiadów. Takie epatowanie zagrożeniem, które czyha z każdej strony wzmacnia siłę przekazu.

Ukraińcy, przez wzgląd na swą rzekomą inność, prezentowani sąjako zagrożenie, którego należy unikać lub wręcz starać się je wyeliminować. Widać to w pojawiających się często wezwaniach do działania przejawiających się w hasłach sprzeciwu wobec ukraińskiej imigracji:

„Nie wpuszczać banderowców !!!!”

„My Polacy WAS tutaj nie chcemy,"

„precz z Polski ruskoukrainskie ścierwo”

Charakterystyczne jest także to, że odpowiedzialność za zbrodnię 1943 roku cedowana jest na całe współczesne społeczeństwo ukraińskie. Uzasadnieniem dla takiej retoryki ma być - po pierwsze - szczególne okrucieństwo tych zbrodni ( „Martwy mężczyzna z bagnetami w oczach Zarżnięta Matka z flakami na wierzchu Unoszący się zapach krwi w powietrzu”), które świadczyć ma o zezwierzęceniu i czymś w rodzaju morderczej czy bandyckiej natury jako cechy narodowej, po drugie zaś - odpowiedzialność polskich potomnych za pamięć o bezimiennych ofiarach Wołynia.

Bardzo często w tym kontekście pojawiają się również komentarze dotyczące braku oficjalnych przeprosin i przyznania się do winy ze strony władz Ukrainy:

„Ukraińcy mieli 25 lat lat na to, żeby rozliczyć się za rzeż wołyńską! Dlaczego tego nie zrobili? To tchórze! Teraz chowają się za "wojną" z Rosją.... 
Nic się nie zmieniło! Tchórz i ludobójca nigdy nie weźmie odpowiedzialności za swoje czyny! NIE DLA UKRAINY !!!"

„Polska przeprosiła za "akcję Wisła" niemal natychmiast po 1989. Ukraina nie musi przepraszać za 10000x brutalniejszy Wołyń, bo "jest młoda"."

Brak stanowczego, jednoznacznego oświadczenia i przeprosin ze strony władz ukraińskich, informacje na temat polityki edukacyjnej Ukrainy, w której brakuje nauczania na temat wydarzeń wołyńskich, odradzający się kult Bandery są dla wielu polskich internautów dowodami na to, że na współczesnych Ukraińców można przekładać odpowiedzialność za 1943 rok, bo od tego czasu właściwie nic się nie zmieniło. J est to również powodem zamiennego stosowania słów „Ukrainiec”, „upainiec” i „,banderowiec". Przez wzgląd na wydarzenia historyczne odmawia się też współczesnym Ukraińcom prawa do państwowości:

„J a dodam od siebie, że państwo, które buduje swoją świadomość narodową na morzu bestialsko przelanej krwi, nie może oczekiwać nawet przychylnego nastawienia do siebie"

Pojawiają się także sugestie dotyczące ewentualnego „przywrócenia sprawiedliwego porządku", czyli de facto zbrojnej interwencji na Ukrainie:

„Ukry kultem upa proszą się o rozbiór prewencyjny, jak widać sprawy idą w tym kierunku."

oraz poglądy, że Polska nie może zająć Ukrainy lub w inny sposób przejąć kontroli nad jej terytorium, ale tylko dlatego, że niosłoby to zagrożenie dla naszego bezpieczeństwa wewnętrznego ze względu na niższość kulturową jej obywateli:

„nie ma co zrobic z Ukraincami tam mieszkajacymi a protektoratem polskim byc nie moga ze wzgledu na ich zainfekowane sowiecka mentalnoscia osobowisci Okupacja sowiecka od 1939 roku zrobila z Ukraincow zlodzieji , malwersantow, leni , roszczeniowcow i kosmopolitan czyli 
takich ktorzy nie dbaja o swoja ojczyzne Sowiecki system gdzie wszystko bylo wspolne spowodowal bardzo daleko posunieta degradacje spolecznestwa ukrainskiego pod tym wzgledem Dla Polski to bylby kompletny chaos ktory grozilby wojna domowa A tak apropo to niewiele lepej jest w Rosji z tym tylko ze oni NA RAZIE zyja z wyprzedarzy ropy i gazu”

„Banderowcy, znam Polaków którzy po wojnie pozostali w Polskim Lwowie i mi mówili, że jak wkroczyli banderowcy do polskich mieszkań to nie można ich było nauczyć, że z sedesu nie pije się wody. Kim wy jesteście. Czy ktoś kiedykolwiek słyszał o jakimś ukraińskim naukowcu? Całe szczęście, że jesteście tacy tępi bo jakbyście opanowali np. obsługę karabinu to zabilibyscie miliony ludzie a tak widłami i siekierami idzie wam wolniej. UKRAINA TO KRAJ KTÓRY NIE POTRAFI NAWET WYPRODUKOWAĆ DREWNIANYCH ŁYŻEK I GLINIANYCH MISEK !!!!!!!!!!!!!!!!!!!!!!!!!!!!!!!!!!!!!!!!!!!!!!!!!!!!!!!!!!!!!!! UKRAINA jest za afrykańskimi Rwandą, Czadem i Gabonem ... w spadku PKB ( -17\%) i bilansie handlowym ( - 761 MLN \$) ALE wyprzedza ..Rwandę w poziomie zarobków 42,9 \$ do 20 \$”

Ewaluacyjny wymiar stereotypu Ukraińca powielanego w tego typu wypowiedziach jest na tyle jednoznaczny i mocny, że rodzi pytania o przyczyny takiego stanu rzeczy. J ego źródeł szukać należy - w moim przekonaniu - w odradzających się w Europie nacjonalizmach. Nawet jeśli uznamy, że Polska nie została bezpośrednio dotknięta przez światowy kryzys finansowy 2008 roku, to zauważalny jest u nas - będący jego efektem - wzrost poparcia dla ideologii skrajnie prawicowych - nawołujących do powrotu do, tak zwanych tradycyjnych wartości i odbudowy silnych państw narodowych. „Dotkliwe przeżycia, krzywdy doznane od grupy dominującej lub sąsiadów cementują naród” twierdzi Małgorzata Budyta-Budzyńska (2013: 84). Stąd sięgnięcie po doświadczenia 1943 roku może być próbą budowania współczesnej wersji tradycji narodowej, w której największym wrogiem Polaków mieliby być Ukraińcy właśnie. „Do tradycji należy ta część dorobku kulturowego grupy, która ma 
dla niej szczególne znaczenie i wyjątkową wartość w obecnym momencie. (...) J est wiele historycznych przykładów pokazujących, jak zmiana systemu wartości, ideologii , niekiedy sojuszników i sytuacji politycznej przewartościowywaly tradycję" (ibidem:103). Niewykluczone, że tak też dzieje się i tym razem, wszak wykreowanie konfliktu, nawet jeśli miałby on być nierzeczywisty, służy budowaniu tożsamości grupy własnej, utrwalaniu jej spójności poprzez wymuszanie zaangażowania członków i wyłonieniu się liderów (Coser 2009). Obecność imigrantów z Ukrainy w Polsce ułatwia zrobienie z nich „wrogów narodu polskiego”.

Autor cytowanego wcześniej tekstu hip-hopowego stara się wejść w rolę nauczyciela i wychowawcy, który w sytuacji budowania spolecznego poparcia dla naszych sąsiadów zmagających się z trudną sytuacją wewnętrzną, przestrzega swoich rodaków przed jednoczeniem się z Ukraińcami ze względu na pamięć rzezi wołyńskiej. Właśnie owa pamięć powinna, jego zdaniem, budować polską wspólnotę i niechęć względem Ukraińców („My, Polacy nosimy w sercach blizny historii o Wołyniu"). Taki mentorski ton pojawia się w wielu wypowiedziach. Znajomość historii prezentowana jest w ogóle jako obowiązek nie tylko patrioty, ale „każdego myślącego” człowieka. Ma ona uchronić nas przed przyszłymi zagrożeniami, zwłaszcza w sytuacji fałszowania prawdy historycznej, jakie - w przekonaniu internautów, których wypowiedzi analizowałam - odbywa się w ukraińskich szkołach:

„Po pierwsze to z historii nigdy nie miałem gorszej oceny niż 5 więc się znam i wiem ile szkody wyrządzili nam Ukraińcy i nie uczyłem się tylko historii, której uczą lecz czytałem na ten temat różne książki i informacje na internecie proszę pana."

„a jakjuż się chcesz odnosić to historii to wypadałoby się dokształcić czy może coś boleć Ukraińców od tysiąca lat jak Ukraina powstała w latach $90 \mathrm{XX}$ w??? w czasach o których piszesz to w oborze u polskiego lub ruskiego spolszczonego Pana pracował równie Polski chłop który był przesiedlony na te ziemie kresowe najczęściej z Mazowsza”. 
Wiedza historyczna ma budować świadomość narodową i być orężem w dyskusjach internetowych:

„do ludzi myślących: nie dajcie się ukraińskim/banderowskim »trollom«".

Ważną cechą wypowiedzi publikowanych w mediach społecznościowych jest również zauważalna jednoznaczność oceny historycznej. Zdaniem polskich internautów przyczyną rzezi wołyńskiej jest wrodzona Ukraińcom skłonność do zbrodni i okrucieństwa („Nie zabijali tak po prostu, to sprawiało im radość”). Pojawiają się co prawda nazwy organizacji nacjonalistycznych, jak OUN czy UPA, ale zlewają się one z całym obrazem społeczeństwa. Zakłada się, że powstały w wyniku radykalizacji poglądów i postaw wszystkich Ukraińców, a nie - co bliższe jest prawdzie historycznej - prowadziły działania polityczne mające służyć rozbudzeniu tożsamości narodowej opartej miedzy innymi na niechęci czy też nienawiści względem Polaków.

Współwystępowanie figury wroga z propagowaniem własnej wersji historii i próbą „zaniesienia jej pod strzechy” charakterystyczne są dla dyskursu nacjonalistycznego (Wrzosek 2015: 352). Poczucie zagrożenia służyć ma budowaniu jedności narodowej, zaś nauczanie swojej wersji historii, w jej nacjonalistycznej interpretacji, jest narzędziem swoistej pracy u podstaw kładącej fundament pod rozwój ruchów skrajnie prawicowych.

Uwagi wymaga także język wpisów, który charakteryzuje się bardzo wysokim poziomem wulgarności („Banderowskie ścierwo”, „kurwożydy”, „A nagonka na Polskich Patriotów jacy oni by nie byli jest prawdziwym SKU...SYŃSTWE*”), a także pogardy, bądź jawnej agresji wstosunku do naszych sąsiadów:

„J akbyś uczył się Polskiej historii to byś wiedział ile krwi przelaliśmy za niepodległość, to wy jesteście sztucznym narodem wiecznie gwałconym przez Rosję wierzycie że pochodzicie od Kozaków, którzy ujawnili się 
wXIXw to nawet kraje afrykańskie mają dłuższą historię, zarówno kozacy byli ruchani jaki obecni Banderowcy wsztucznym państwie, które nigdy nie powinno istnieć czyli Ukraina, państwo morderców,gwałcicieli polecam się pouczyć kogo zsyłano na Zaporoże czyli główne ziemie tych "Kozaków" to byli sami mordercy, którzy byli zbiegami, a tak poza tym to mam nadzieję że was tam Rosja ładnie wyrucha takjak kiedyś :)"

Widać tu próbę zbudowania narracji historycznej przy udziale dyskursu eksperckiego, ponieważ autor uważa się za osobę znającą historię w przeciwieństwie do oponenta, do którego wypowiedzi się odnosi. Abstrahując od tego, że jest to zbiór nie tyle nawet uproszczeń, co przekłamań historycznych7, to pobrzmiewa tu ponownie dyskurs nie tylko antyukraiński, ale też ksenofobiczny - autor sugeruje, że wstydliwe jest posiadanie krótszej historii nawet od państw afrykańskich, co zdradza pewną niechęć czy też pogardę dla tychże.

Mimo specyfiki języka internautów, którzy mają często dość swobodne podejście do zasad poprawnej pisowni, to nawet na tym poziomie zauważalne są zabiegi, które mają być obraźliwe w stosunku do Ukraińców, np. pisanie nazwy ich państwa i narodowości z małej litery. Bardzo często wjednym zdaniu znaleźć można „Polskę i ukrainę” czy „Polaka i ukraińca”. Niekiedy też małą literą pisane są nazwiska znanych Ukraińców, bądź imiona uczestników internetowych dyskusji, którzy wyjawili, że są Ukraińcami.

„J escze jedno ucz sie pieknego jezyka polskiego bo masz z nim bardzo powazne problemy, mykola."

Taki zabieg ma być upokarzający względem wschodnich sąsiadów, a zarazem ma sugerować wyższość Polski i Polaków.

7 Nie rozstrzygam czy przekłamania te są zamierzone, czy odzwierciedlają rzeczywistą wiedzę lub/i przekonania autora. 
Podobną funkcję pełni stosowanie dehumanizujących określeń i sformułowań jak „dzicz”, „swołocz”, „zwierzęta”, „bydlaki”, np.:

„Mają tupet ci Ukraińcy. Mordować dzieci, kobiety w tak okrutny sposób to jest DZICZ!"

Niewątpliwie ważnym impulsem do dyskusji na temat wątków historycznych wrelacjach polsko-ukraińskich stała się premiera filmu Wotyń Wojciecha Smarzowskiego. O ile jednak w wypowiedziach internautów pojawiają się wzmianki o tym, że dobrze, iż film powstał, że ktoś wreszcie podją temat,

„Ogarnij,że do premiery filmu Wołyń za wspominanie o Wołyniu nader często można było zostać określonym per »Ruski Troll«"

o tyle trudno znaleźć wypowiedzi odwołujące się wprost do scen z filmu. Można więc odnieść wrażenie, że niewielu uczestników dyskusji zobaczyło ten film na własne oczy. Przypuszczam, że część obrazów tortur czy też sposobów zabijania, które pojawiają w wypowiedziach internautów pochodzi właśnie z filmu bądź doniesień prasowych z premierą związanych, ale brak w zasadzie wypowiedzi, które sugerowałyby, że film Wołyń poszerzył wiedzę autora; mówi się raczej, że dobrze, że powstał, bo wreszcie poznają prawdę (jacyś inni) Polacy i Ukraińcy, nieświadomi własnej historii.

Zazwyczaj uczestnicy debaty przytaczają wyrywki ze swej wiedzy, a niekiedy również dane statystyczne, nie powołując się jednak na żadne źródła. J eśli już źródła są wskazywane to bywają to linki do artykułów ze strony TV Republika, portali o charakterze nacjonalistycznym czy filmików w serwisie YouTube. Pojawiają się również odwołania do opowieści zasłyszanych od babć, wujów czy sąsiadów, a niekiedy także wpisów przeczytanych podczas wcześniejszych debat internetowych. Co ciekawe, jako źródło wiedzy na temat historii Ukrainy i mentalności Ukraińców często wskazuje się również powieści Henryka Sienkiewicza. 
Zauważyć jednak należy, że o poszerzanie wiedzy historycznej i sięganie po nią apelują również oponenci osób o prezentowanych wyżej poglądach:

„Widzę tu tylko ogólny brak wiedzy historycznej i podawanie nie do końca trafionych przykładów. My też niejesteśmy sweci w sprawie Ukrainy chodzby akcja Wisła."

„Pamiętajmy, że to nasza szlachta nadziewala na pal.”

Wypowiedzi takich jak powyższe jest zdecydowanie mniej i spotykają się zwykle z ostrą krytyką oraz oskarżeniami o stronniczość lub brak rzetelnej wiedzy, ale odnotować należy ich obecność. Są obecne także głosy stające w obronie Ukraińców i starające się apelować do sumień szczególnie agresywnych uczestników dyskusji:

„J esteśmy tacy sami! Tylko jak zwykle o tym zapominamy."

J ednak jest ich - zwłaszcza w wątkach poświęconych historii - stosunkowo niewiele.

Dyskusja

Pamiętając o tym, iż Internet jest medium specyficznym i jego użytkownicy, dzięki fałszywemu poczuciu anonimowości, mają dużą łatwość w wyrażaniu poglądów skrajnych, których będąc offline nigdy by nie wypowiedzieli, należy jednak mieć na uwadze, że tego typu wypowiedzi, szczególniejeśli obecne są w dużej masie, mogą trafić na podatny grunt. Nawet jeśli ruch narodowy nie urośnie w siłę, która mogłaby zagrażać porządkowi społecznemu, to poziom agresji prezentowany w Internecie może zmobilizować do działania grupy, bądź jednostki, które z poczuciem misji będą starały się „bronić” ojczyzny przed zagrożeniem ze strony owych „obcych”, stosując przemoc wobec ukraińskich imigrantów czy też osób popierających ich przyjazd do Polski. Egzemplifikacją 
możliwych skutków takiej niechęci wobec przedstawicieli jakiejś grupy były norweskie zamachy, których dokonał w 2011 Anders Breivik.

Również w Polsce mieliśmy już do czynienia z przejawami agresji względem imigrantów z Ukrainy - wykaz takich przestępstw i wykroczeń w całym kraju, opis szczególnie trudnej sytuacji w przygranicznym Przemyślu oraz Informację dotyczącą profanowania i niszczenia grobów i upamiętnień związanych z mniejszością ukraińską w Polsce (20142016) prezentuje Raport. Mniejszość ukraińska i imigranci z Ukrainy w Polsce. Analiza dyskursu. Praca zbiorowa (2018: 30-80).

W narracji na temat Ukraińców w polskim Internecie dochodzi do niebezpiecznego spotkania ksenofobicznych, nacjonalistycznych i eksperckich narządzi dyskursywnych. Obywatele Ukrainy stali się nowym wrogiem, który niezbędny jest do budowania siły ruchów nacjonalistycznych. Co więcej jest to wróg znacznie wygodniejszy od „używanych do tego celu” w ostatnich dekadach feministek czy środowisk lewicowych (Wrzosek 2015: 5). Atrakcyjność Ukraińoów, jako nowych wrogów narodu polskiego tkwi w potencjale, który daje trudna i nie przedyskutowana polsko-ukraińska historia. Wydarzenia sprzed 75 lat służą polskim nacjonalistom jako uzasadnienie do prezentowania współczesnych Ukraińców jako bezpośredniego zagrożenia. Przemoc symboliczna przejawiająca się w języku narracji o Ukraińcach jest jednym z narzędzi, po które środowiska nacjonalistyczne sięgają próbując zdobyć realną władzę.

Widoczne jest zainteresowanie internautów wiedzą historyczną, a jednocześnie brak umiejętności jej zdobywania i krytycznego do niej podejścia. Sytuacja taka z jednej strony jest zagrożeniem, ponieważ pozwala na wchodzenie w rolę ekspertów ludziom, których intencją jest budowanie swojej siły politycznej na lęku przed obcymi. Z drugiej jednak strony daje ono duży potencjał do działania do promowania wiedzy opartej na faktach. Wymagało by to jednak zaangażowania instytucji, które byłyby zainteresowane zmianą zaistniałej sytuacji, a jednocześnie gotowe do podjęcia działań na gruncie nowych mediów - edukatorów, 
którzy rozumieją specyfikę narzędzi interaktywnych i języka internetowego. Dyskurs i społeczeństwo współoddziałują, zatem działania skie rowane do jego uczestników wpłyną na jego ksztalt i prowadzić będą do dalszych zmian służących złagodzeniu poziomu agresji i podziału na „my i oni”. Bez wątpieniajednak nie będzie to zadaniełatwe przez wgląd na trwałość stereotypów, jak pisze Budyta Budzyńska, „niejednokrotnie trudno zmienić stereotyp, nie jest bowiem jasne co było realnym doświadczeniem grupowym, a co jego symboliczną interpretacją. Wydarzenia obrosły takimi mitami i legendami, że trudno dociec, jak było naprawdę, co właściwie się zdarzyło, a co zostało później dodane, podretuszowane, co jest opisem, a co produktem wyobraźni i zbiorowych resentymentów. Stereotypy W zasadniczym stopniu wywodzą się z tradycji, ustnych podań, przekazów literackich, dlatego trudno je zmodyfikować przez dowody akademickiej wiedzy" (Budyta-Budzyńska 2009: 118).

Bibliografia

Budyta-Budzyńska M. (2013), Socjologia narodu i konfliktów etnicznych, Wydawnictwo Naukowe PWN, Warszawa

Coser L.A (2009), Funkcje konfliktu społecznego, Zakład Wydawniczy NOMOS, Kraków

Dijk T. van (2001), Dyskurs jako struktura i proces, Wydawnictwo Naukowe PWN, Warszawa

Grzymała-Kazłowska A. (2004), Socjologicznie zorientowana analiza dyskursu na tle współczesnych badań nad dyskursem, „Kultura i Społeczeństwo" nr 48 (1)

Herma M. (2014), Pisany język mówiony, „Polityka - Niezbędnik inteligenta", http:/ / www.polityka.pl/ niezbednikinteligenta/ 1531529,1,p isany-jezyk-mowiony.read [02.05.2017] 
J abłońska B. (2006), Krytyczna analiza dyskursu: refleksje teoretyczno-metodologiczne, „Qualitative Sociology Review”, Vol. II, No. 1, http:// www.qualitativesociologyreview.org/PL/Volume2/PSJ_2_1 Jablonska.pdf [02.05.2018]

Krzyżanowska N. (2013) (Krytyczna) analiza dyskursu a (krytyczna) analiza gender: zarys synergii teoretycznej i metodologicznej, „Przegląd Socjologii J akościowej” t. 9, nr 1, http:// www.academia. edu/12714470/_Krytyczna_analiza_dyskursu_a_krytyczna_analiza_gender_zarys_synergii_teoretycznej_i_metodologicznej_Natalia_Krzy\%C5\%BCanow [26.06.2017]

Malewska-Szałygin A. (2004), Tradycja stosowania pojęcia dyskurs ijego przydatność $w$ antropologii wspótczesności, „Etnografia Polska” t. XLVIII, http:// cyfrowaetnografia.pl/Content/ 1617/ Strony\%20od \%20EP_XLVIII-6_Malewska.pdf [20.06.2017]

Motyka G. (2011), Od rzezi wolyńskiej do akcji „Wista”, Wydawnictwo Literackie, Kraków

Motyka G. (2016), Wolyń '43, Wydawnictwo Literackie. Kraków Raport. Mniejszość ukrainsska i migranci z Ukrainy w Polsce. Analiza dyskursu. Praca zbiorowa, (red.) Tyma P., Związek Ukraińców w Polsce, Warszawa, http:// www.siectolerancji.pl/sites/default/files/ma ly_raport_mniejszosc_internet.pdf [15.03.2018]

Reid A. (2016), Pogranicze. Podróż przez historię Ukrainy 988-2015, Wydawnictwo Literackie, Kraków

Sulikowski A. (2014), Perspektywy zastosowań metod Krytycznej Analizy Dyskursu w badaniach nad prawem: kilka uwag, http:// www.repozytorium.uni.wroc.pl/Content/ 64493/ 06_Sulikoski_A_ Perspektywy_zastosowan_metod_Krytycznej_Analizy_Dyskursu _w_badaniach_nad_prawem_Kilka_uwag.pdf [20.06.2017] Sydow K. (20016), Troska, strach, wrogość. Dyskurs o uchodźcach i migrantach $w$ Polsce $i$ Niemczech, https://pl.boell.org/pl/2016/07 
/ 25/ troska-strach-wrogosc-dyskurs-o-uchodzcach-i-migrantach-wpolsce-i-niemczech [15.03.2018]

Troszyński M. (2018), Ukraina i Ukraińcy w polskim dyskursie internetowym. Analiza jakościowo-ilościowa tekstów zamieszczanych $w$ mediach spotecznościowych, w: Raport. Mniejszość ukraińska i migranci z Ukrainy $w$ Polsce. Analiza dyskursu. Praca zbiorowa, (red.) Tyma P., Związek Ukraińców w Polsce, Warszawa, http:// www. siectolerancji.pl/sites/default/files/maly_raport_mniejszosc_internet.pdf [15.03.2018]

Uchwała Sejmu Rzeczypospolitej Polskiej z dnia 12 lipca 2013 r. w sprawie uczczenia 70. Rocznicy Zbrodni Wołyńskiej i oddania hołdu J ej ofiarom, https:// pl.wikisource.org/ wiki/Indeks:Uchwa\%C5\%82a_S ejmu_Rzeczypospolitej_Polskiej_w_70._rocznic\%C4\%99_Zbrodni _Wo\%C5\%82y\%C5\%84skiej [17.06.2017]

Uchwała Sejmu Rzeczypospolitej Polskiej z dnia 22 lipca 2016 r. wsprawie oddania hołdu ofiarom ludobójstwa dokonanego przez nacjonalistów ukraińskich na obywatelach II Rzeczypospolitej Polskiej w latach 1943-1945, http:// orka.sejm.gov.pl/proc8.nsf/uchwaly/ 625 _u.htm [19.06.2017]

Witosz B. (2010), O dyskursie wykluczenia i dyskursach wykluczonych z perspektywy lingwistycznej, http:/ / bazhum.muzhp.pl/media/ / files/Tekst_i_Dyskurs_Text_und_Diskurs/Tekst_i_Dyskurs_Text und_Diskurs-r2010-t3/Tekst_i_Dyskurs_Text_und_Diskurs-r201 0-t3-s9-25/Tekst_i_Dyskurs_Text_und_Diskurs-r2010-t3-s9-25. $\operatorname{pdf}[15.03 .2018]$

Wodak R. (2008), Dyskurs populistyczny: retoryka wykluczenia a gatunki języka pisanego, w: Krytyczna analiza dyskursu: interdyscyplinarne podejście do komunikacji spotecznej, ( red.) Duszak A., Fairclough N., Universitas, Kraków

Wrzosek T. (2015), Dyskurs nacjonalistyczny w Polsce - główne idee. "J ournal of Modern Science", No 3 (26) 